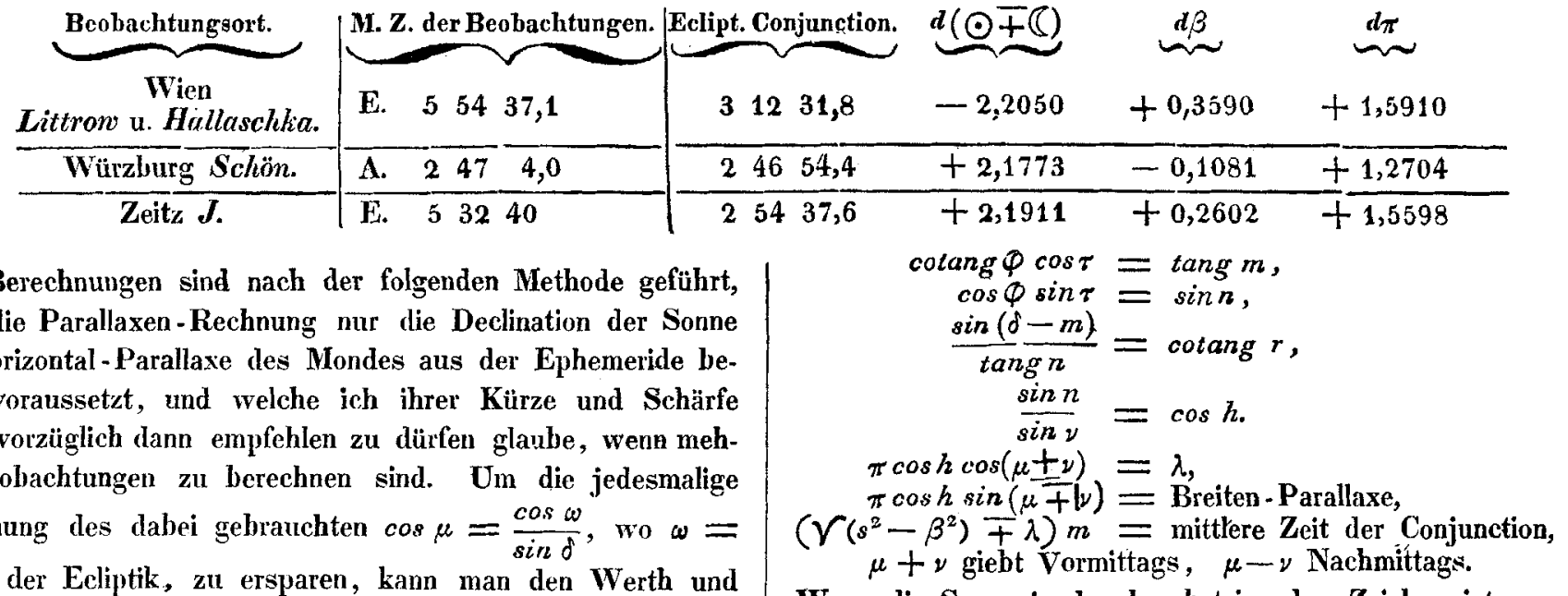

Diese Berechnungen sind nach der folgenden Methode geführt, worin die Parallaxen-Rechnung nur die Declination der Sonne und Horizontal-Parallaxe des Mondes aus der Ephemeride bekannt voraussetzt, und welche ich ihrer Kürze und Schärfe wegen vorzüglich dann empfehlen zu dürfen glaube, wenn mehrere Beobachtungen zu berechnen sind. Um die jedesmalige Berechnung des dabei gebrauchten $\cos \mu=\frac{\cos \omega}{\sin \delta}$, wo $\omega=$ Schiefe der Ecliptik, zu ersparen, kann man den Werth und die stïndliche Veränlemng von $\mu$ für eine gegebene Zeit berechnen. Hier ist $\mu$ fiir mittl. Mittag in Greenw. $75^{\circ} 53^{\prime} 40^{\prime \prime} 6$, stündl. Veränderung $+48,37$. Die Verminderung des Sonnenhalbmessers ergiebt sich aus der Formel

$$
r=\sin h \cdot \sin R \cdot \pi+2 R \sin ^{2} \frac{x}{3} R,
$$

worin das letzte Glied verschwindet. Die schliefslich beigefügte Tafel erspart aber auch diese Rechnung. Man setze demnach $\varphi=$ geoc. Brcite, $\tau=$ wahre Zeit der Beobachtung, $\delta=$ Nordpolardistanz der Sonne, $\pi=$ Unterschied der Horizontalparallaxen am Beobachtungsorte, $\beta=$ scheinbarer Unterschied der Sonnen - und Mondesbreiten, $\lambda=$ Längenparallaxe, $R=$ Sonnenhalbmesser, $\rho=$ geocentr. Moudeshalbmesser, $S=R-r+\rho$ und $m=\frac{3600^{\prime \prime}}{\text { relative stündliche Bewegung in Länge }}$. Dann ist
Wenn die Sonne in den herabsteigenden Zeichen ist, so muls $180^{\circ}-\mu$ stalt $\mu$ gesetzt werden.

Tabelle fiur die Vorminderung des Sonnenhalbmessers.
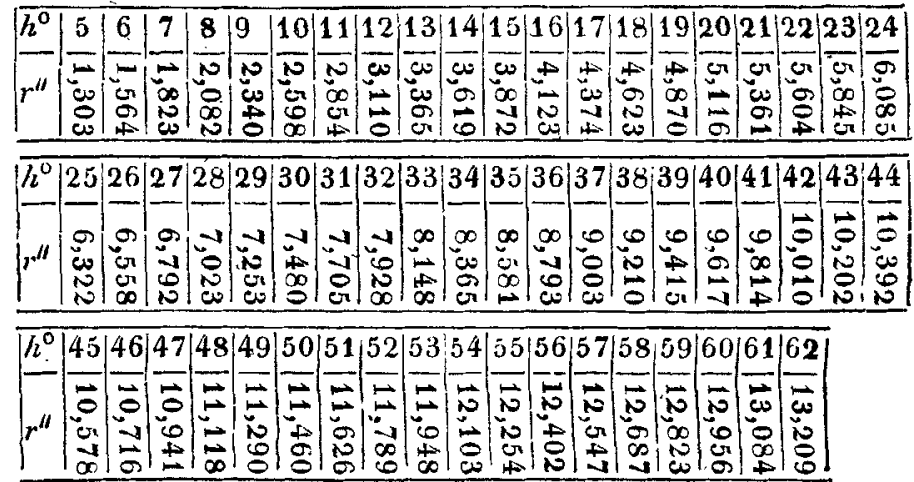

Rümker.

\title{
Refractions of Stars near the Horizon observed at the Cape of Good Hope.
}

Observatory Edinburgh, September 13, 1836.

A number of obscrvations were made by me, in the years 1832 and 1833, with the Mural Circle of the Observatory at the Cape of Good Hope, of the apparent Zenith distances of Stars; which passed the Meridian, at greater Zenith distances than $85^{\circ}$. The Stars observed were on both sides of the Zenith. From the known Declinations of the Stars, and the Latitude of the Observatory $33^{\circ} 66^{\prime} 3^{\prime \prime} 2$ South, the true Zenith distances are obtained, and the differences betwixt the true and observed Zenith distances are the observed refractions. The Declinations of the southern stars have been taken from my Catalogue deduced from observations at the Cape of Good Hope. The Declinations of the northern Stars have been assumed as follows, the epoch being January 1, 1833.

$$
\begin{array}{ll}
\gamma \text { Draconis } & 51^{\circ} 30^{\prime} 42^{\prime \prime} 0 \\
\beta \text { Draconis } & 522540,6
\end{array}
$$

$$
\begin{array}{llll}
\theta \text { Ursæ Majoris } & 52^{\circ} 25^{\prime} & 59^{\prime \prime} 8 \\
\gamma \text { Ursæ Majoris } & 54 & 37 & 23,6 \\
\alpha \text { Cassiopeæ } & 55 & 37 & 12,9
\end{array}
$$

The refractions have been computed from the Tables of MM. Bessel and Ivory, The mean refractions of M. Bessel, taken from the Fundamenta Astronomix, have been increased in the proportion of 1 to 1,003282 , as directed in the $\mathrm{T}$ abulæ Regiomontanæ for Zenith distances lefs than $85^{\circ}$, the factors for reducing the mean refractions to the given states of the Barometer and Thermometer having been taken from the Tabulæ Regiomontanæ. Mr. Ivory's refractions have been computed from his Tables given in the Philosoph. ical Transactions for 1823. The differences betwixt the observed and computed refractions are the corrections of the Tables; and the mean of all the corrections for each Star 
is held to be the correction of the refraction computed from the Tables for the mean Zenith distance and altitude of the Barometer and Thermometer. The computed refractions being corrected accordingly we have the observed refractions corresponding to the mean Zenith distances and altitudes of the Barometer and Thermometer. The results are contained in the. subjoined Table, which likewise exhibits the probable error of one observation of each star computed from the formula

$$
(n-1) \varepsilon^{2}=(0,6745)^{2} s
$$

$n$ denoting the uumber of observations, $\varepsilon$, the probable error of one observation, and $s$, the sum of the squares of the differences between the mean correction and every single one

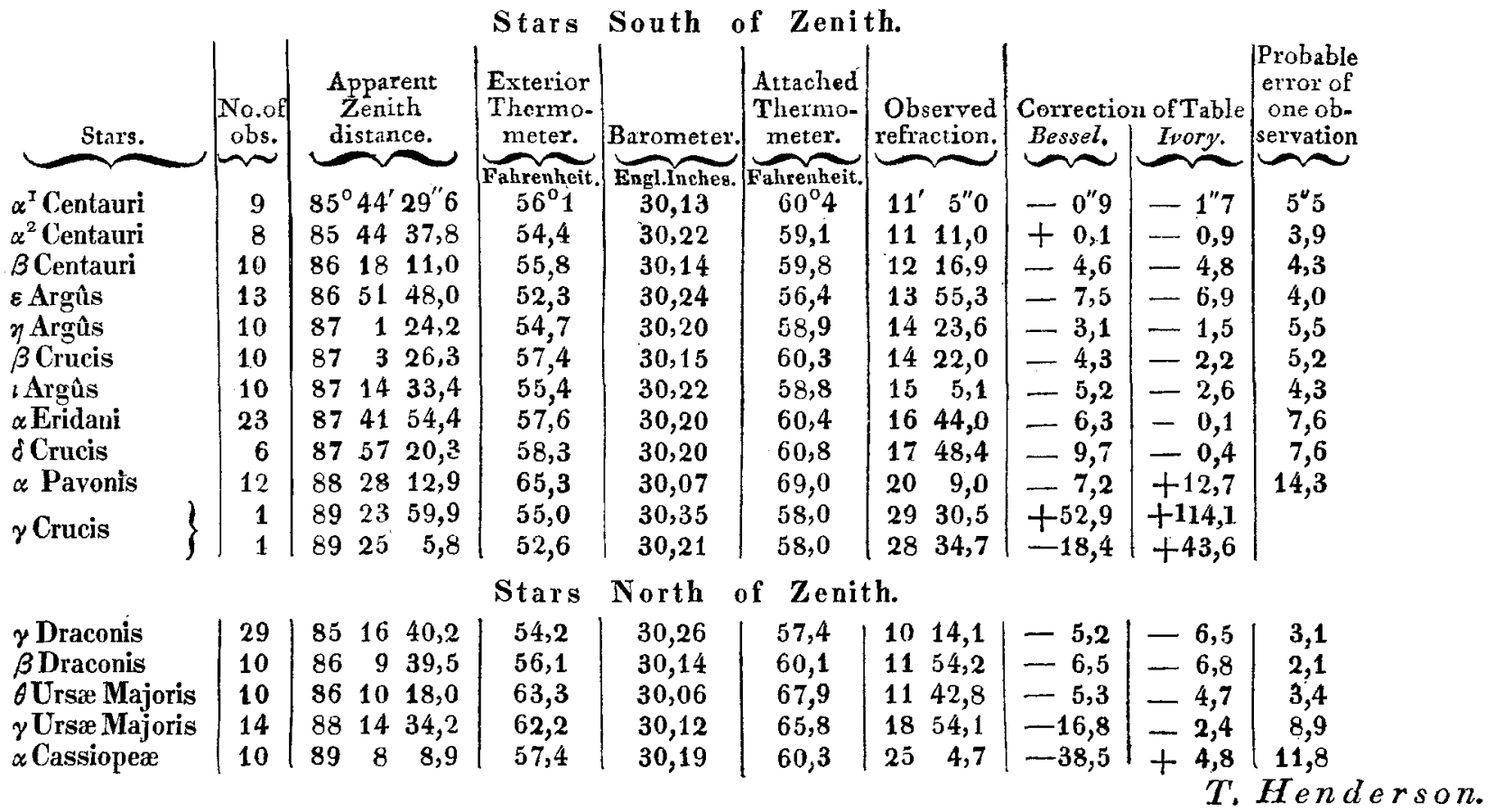

Schreiben des Herrn Koller, Directors der Sternwarte in Kremsmünster, an den Herausgeber. Kremsmünster 1836. März 19.

Erst heute kann ich Ihnen die im verflossenen Jahre am Meridiankreise der hiesigen Sternwarte gemachten Beobachtungen des Mondes und der Mondsterne übersenden, indem mich bis jetzt andere Arbeiten daran gehindert. Die Beobachtungen sind sämmtlich von Herrn Aug. Reslhuber, Adjuncten der hiesigen Sternwarte, reducirt, dessen thätiger Mithülfe ich mich seit einem Jahre erfreue, und der sich mit allem Eifer der Astronomie widmet. Ich habe zugleich die wenigen Sternbedeckungen beigefügt, die wir 1835 erhalten konnten. Halley's Co-

1835 Dec. 22. 1836 Jan. 6.$$
7 .
$$

8.

9.

14.

21.

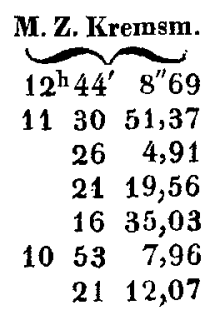

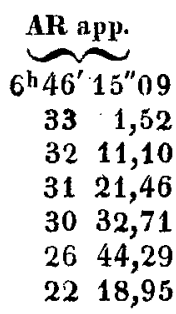

meten konnte ich seit seinem Perihel nur zweimal beobachten; zuerst 1836 Jan. 21 und dann Febr. 16, jedesmal jedoch sehr lichtschwach und unter so ungünstigen Umständen, dafs ich seinen erhaltenen Positionen wenig Vertrauen schenken kann, und sie deshalb hier nicht beifüge; wohl aber bin ich so frei dieses mit den wenigen Beobachtungen zu thun, die wir bei der letzten Opposition der Juno am Meridiankreise erhielten. Sie sind von Refraction und Parallaxe befreit, und mit Encke's Jahrbuch verglichen.

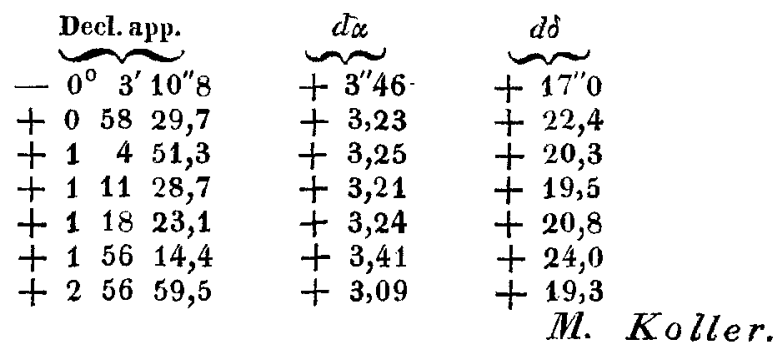

